\title{
Joe Brainard's I Remember, Fragmentary Life Writing and the Resistance to Narrative and Identity
}

\section{ABSTRACT}

Paul Ricoeur declares that "being-entangled in stories" is an inherent property of the human condition. He introduces the notion of narrative identity-a form of identity constructed on the basis of a self-constructed life-narrative, which becomes a source of meaning and self-understanding. This article wishes to present chosen instances of life writing whose subjects resist yielding a life-story and reject the notions of narrative and identity. In line with Adam Phillips's remarks regarding Roland Barthes by Roland Barthes (1975), such works-which I refer to as fragmentary life writing - emerge out of a profound scepticism about any form of "fixing" oneself and confining the variety and randomness of experience to one of the available autobiographical plots.

The primary example of the genre is Joe Brainard's I Remember (1975) an inventory of approximately 1,500 memories conveyed in the form of radically short passages beginning with the words "I remember." Despite the qualified degree of unity provided by the fact that all the recollections come from the consciousness of a single person, the book does not arrange its content in any discernible order-chronological or thematic; instead, the reader is confronted with a life-in-fragments. Although individual passages could be part of a coming-of-age, a coming-out or a portrait-of-theartist-as-a-young-man narrative, Brainard is careful not to let any of them consolidate. An attempt at defining the characteristics of the proposed genre will be followed by an indication of more recent examples of fragmentary life writing and a reflection on its prospects for development.

Keywords: fragmentation, life writing, experimental literature, narrative identity. 
This article will begin with a brief discussion of the importance of narrative and identity to life writing. It will then propose a new autobiographical genre-fragmentary life writing-which is based on the rejection of both of those paradigms. A brief discussion of the poetics and politics of fragmentary life writing - using the example of Roland Barthes's antiautobiography Roland Barthes by Roland Barthes (1975)—will be followed by a closer examination of Joe Brainard's I Remember as a representative of the genre. The article will argue that the postulated genre, situated within Irene Kacandes's category of experimental life writing, is informed by a radical scepticism about the givens of autobiography and portrays life as an amalgam of arbitrarily interwoven shards of experience, not amounting to any coherent life-story and failing to provide a firm foundation for a stable self.

\section{Narrative, Identity, Autobiography}

Perhaps the most important advocate of the interdependence of narrative and identity was Paul Ricoeur, whose conclusions have been synthesized by Karl Simms in the following statement: "we understand our own lives-our own selves and our own places in the world-by interpreting our lives as if they were narratives, or, more precisely, through the work of interpreting our lives we turn them into narratives, and life understood as narrative constitutes self-understanding" (80). Narrative is thus "the form of discourse which ... is richest in human meaning" (Simms 83). That conviction became the foundation for Ricoeur's concept of narrative identity, which he formulates in his articles "Life in Quest of a Narrative" and "Narrative Identity" (both from 1991). The French philosopher understands it as a "durable character of an individual" based on a life-story whose coherence is imposed by plot, which, in turn, is conditioned by the individual's desired self-image ("Narrative" 77). The vital link between identity and narrative has been recognized by scholars of life writing. In the tellingly titled book How Our Lives Become Stories: Making Selves (1999), Paul John Eakin goes so far as to equate the two concepts by stating that "narrative is not merely an appropriate form for the expression of identity; it is an identity content" (100). In their oft-cited primer Reading Autobiography: A Guide for Interpreting Life Narratives (2001), Sidonie Smith and Julia Watson also assert the connection by defining "life narrative," a subtype of life writing which includes autobiography, as a "set of evershifting self-referential practices that engage the past in order to reflect on identity in the present" (3). 
The implicit assumption behind much of autobiographical writingthat one achieves a greater self-understanding by turning one's life into a narrative-has been challenged by thinkers who view this practice as limiting and dangerous. In the foreword to Roland Barthes by Roland Barthes, British psychoanalyst Adam Phillips articulates the hazards of what Barthes calls "constituting" oneself: ${ }^{1}$

You get stuck with the self you have made up; the story becomes compulsory. In an age of autobiography in which life stories-lives recovered in words-have become our inspirational literature, there is always the risk of fixing ourselves. The quest for singularity, the therapy of becoming oneself, might be a form of arrested development. (iv)

Autobiography emerges as "our modern myth par excellence"-a source of illusory and feeble reassurance, a "fantasy of describing an essential self where there is neither a self nor an essence" (Phillips ix). Barthes hints at his distrust of the notion of a stable subject when he asks himself and the reader of Barthes by Barthes: "You are a patchwork of reactions, is there anything primary in you?" (143, italics original).

The patchwork self, ${ }^{2}$ Barthes appears to decide, needs to be represented in a corresponding manner. Hence Barthes by Barthes takes the form of an amalgam of arbitrarily arranged glossary entries-on subjects ranging from the adjective and exclusion to migraine and the poststructuralist journal Tel Quel. The glossary is preceded by forty pages of photographs from the family archive ${ }^{3}$ (accompanied by concise, elusive captions) ${ }^{4}$

1 In a section of Barthes by Barthes in which the author discusses his work routine, he meditates about the risk of writing: "you constitute yourself, in fantasy, as a 'writer,' or worse still: you constitute yourself" (82, italics original). A similar insistence on the freedom from becoming something or someone and thus fixing oneself is conveyed by Andy Warhol's adage: "I never fall apart, because I never fall together."

2 In "Roland Barthes, Autobiography, and the End of Writing," J. Gerald Kennedy speaks of this "theory of subjective multiplicity" (391).

3 Barthes prefaces them by the admission that "they are the author's treat to himself, for finishing his book" (3).

4 A full-page photo of Roland as a new-born child held in his mother's arms comes with the caption: "The mirror stage: 'That's you”" (21), while an image of Roland as a student sitting on the lawn with a girl is accompanied by the inscription reading, "Where does this expression come from? Nature? Code?" (34). The captions very rarely serve the expected function of explaining the context of the photograph. Rather, they convey Barthes's idiosyncratic reflections triggered by the images. 
and followed by a two-page "Biography" section, whose surprisingly conventional layout and content is upended by the closing summary of Barthes's existence: “(A life: studies, diseases, appointments. And the rest? Encounters, friendships, loves, travels, readings, pleasures, fears, beliefs, satisfactions, indignations, distresses: in a word: repercussions? . . .)" (183). Life is thus-to quote a maximum attributed inconclusively to various authors- - "one damn thing after another," devoid of a teleology or a narrative pattern. Therefore the most appropriate strategy to represent life is parataxis - the collage-like method of juxtaposing elements without any discernible logic. In a section "I like, I don't like," Barthes offers one of the book's many lists:

I like: salad, cinnamon, cheese, pimento, marzipan, the smell of newcut hay (why doesn't someone with a "nose" make such a perfume), roses, peonies, lavender, champagne, loosely held political convictions, Glenn Gould, too-cold beer, flat pillows, toast, Havana cigars, Handel, slow walks, pears.... I don't like: white Pomeranians, women in slacks, geraniums, strawberries, the harpsichord, Miró, tautologies, animated cartoons, Arthur Rubinstein, villas, the afternoon. . . (116)

Barthes gradually abandons the thematic arrangement of his likes and dislikes: after the initial list of favourite foods and flowers comes the haphazard cluster of "loosely held political convictions, Glenn Gould, toocold beer." When food reappears ("toast"), it is sandwiched between "flat pillows" and the duo of "Havana cigars" and "Handel." The latter seems to be an alphabetically motivated juxtaposition, yet the order in which "Havana" and "Handel" are enumerated is not right. The consistent denial of a pattern, warily associated with the illusions of a coherent self and a comforting life-story, is one of the most characteristic traits of Barthes by Barthes.

The reader of Barthes's book comes away with a hazy grasp of the chronology and the key events in the author's life. There is little reference to what Phillips identifies as the "musts" of a self-narrative, including a focus on parents, childhood recollections and sexual relationships. Whereas the autobiographical story "must make some sense of life, find a meaning or a pattern," in Barthes by Barthes neither a story nor a meaning could be said to emerge (Phillips vi). What the reader gains instead is a greater insight into the mind, or intellect, of the writer. Irene Kacandes regards the book as a rare example of life writing-alongside Vladimir Nabokov's Speak, Memory (1951) and Georges Perec's W or the Memory of Childhood (1975)—which puts its author's "mind in action" at the "center of the work" (387-88). 


\section{FRAGMENTARY LIFE WRITING}

In The Routledge Companion to Experimental Literature, Kacandes proposes the critical category of "experimental life writing," in which she situates Barthes by Barthes together with works including Art Spiegelman's Maus (1991), Dave Eggers's A Heartbreaking Work of Staggering Genius (2001) and J. M. Coetzee's Summertime (2009). They are "experimental" in the sense that they use devices not customarily employed in autobiography-such as "techniques to render the layers of the human psyche, split subjectivity or the human experience of time and space-or a non-standard medium (such as the comics) in order to "enhance, reinforce or draw attention to the referential level" (382). Their formal audacity cannot, however, in any way violate the autobiographical pact as prescribed by Philippe Lejeune- "the author, the narrator, and the protagonist must be identical" (5). Referencing the notorious cases of fictionalized memoirs by Bruno Dössekker/Binjamin Wilkomirski and James Frey, Kacandes stresses that any technique whose aim is to "heighten the drama of the story" or "aggrandize the individual" is not acceptable (382).

Such texts resort to "experimental" means driven by their ambition to "convey some aspect of the 'realness' of certain experiences that could not be conveyed as well without pushing at the form itself" (382). Kacandes cites the example of Spiegelman's decision to recount the story of his parents' survival of the Holocaust in the form of a comics using animal characters as motivated by the ambition to assert (more convincingly than by any standard means) the truth that during the war "Jews were as vulnerable as mice in the presence of cats" (383). The choice of an unconventional medium (such as comics) is one out of the four kinds of (auto)biographical innovations considered by Kacandes, the other ones concerning experiments with time, the focus of the work and the "entanglement between the writer and the subject" (385).

To that short list of categories I wish to add one comprising texts which adopt a radically fragmentary form in order to defy the expected coherence of a self-narrative and its illusory effect-a stable identity. In its refusal to consolidate and yield to the whole, the fragment is governed by "a superior rule: that of the breach (heterology): to keep meaning from 'taking”" (Barthes 146-47). The arbitrariness of their arrangement-in accordance with the principle of parataxis-prevents the reader from "settling into a conventional autobiographical narrative" and the "perfect intelligibility of a remembered life" (Phillips xii). The renunciation of the continuous text in favour of unnaturally short paragraphs, the denial of chronological order and the frequent use of quotation and enumeration are among the principal means employed 
by fragmentary life writing to convey the sense of the self as a complex constellation, mosaic or patchwork, irreducible to being enclosed in the neat parameters of a story.

\section{JOE BRAINARD's I REMEMBER}

The only significant literary work by the American visual artist associated with the New York School, ${ }^{5}$ I Remember has never earned wide recognition but it has gained cult status in certain artistic circles in the United States. The illustrious group of its champions includes Georges Perec, Harry Matthews, Edmund White and Paul Auster. Perec and Matthews even wrote their own volumes following Brainard's remarkably simple formula. ${ }^{6}$ The Library of America's publication of Brainard's Collected Writings in 2012, eighteen years after his death from AIDS, testifies to the success of their efforts to secure Brainard a place in the extended canon of twentieth-century American literature. Edinburgh University Press's release of Yasmine Shamma's Joe Brainard's Art (2019)—a collection of academic essays with an afterword from Marjorie Perloff-reinforces Brainard's status as one of the most important artists of the post-war New York avant-garde.

I Remember was first published in 1970 as a 32-page booklet of oneparagraph entries beginning with the words "I remember. .." It was well received, and its seven hundred copies sold quickly, as a result of which Angel Hair Books agreed to publish subsequent instalments of Brainard's peculiar autobiographical project entitled More I Remember (1972), More I Remember More and I Remember Christmas (both 1973). In 1975 all the parts were assembled into a complete edition of over 160 pages, which is the point of reference for this article. My discussion of the book will first

5 Brainard was a friend of all the most important representatives of this movement: John Ashbery, Frank O’Hara, James Schuyler, Anne Waldman and Ted Berrigan. Ashbery, who like most of the others is mentioned several times in the book, called Brainard "one of the nicest artists" he has ever known-"nice as a person and nice as an artist" (1).

6 Following the publication of the Polish edition of I Remember in 2014, Brainard's formula gained popularity in Poland. Among the most evident inspirations are the volumes Wroctare. Pamiętam, że (2015) and Szczecin. Pamiętam, że (2016) - both created out of individual memories submitted by the cities' inhabitants. A possible influence of Brainard can also be traced in Paweł Marcinkiewicz's collection Majtki w górę, majtki w dót (2015), which contains the poem "Pamiętam"—an assemblage of 46 fragmentary memories, each opening with the phrase "Pamiętam." 
concentrate on its fragmentary form and the arbitrary arrangement of its material. I will then examine the autobiographical content of I Remember and the work's correspondence with the earlier outlined principles of experimental and fragmentary life writing. Finally, I shall review the strategies used by Brainard in order to prevent his book from becoming a record of experience reducible to a single or dominant life-narrative and its autobiographical subject from assuming a specific identity.

The complete edition of I Remember consists of close to one thousand five hundred autobiographical snippets which invariably begin with the titular phrase and continue with the content of Brainard's memories, as in the following excerpt from the opening of the book:

I remember my first erections. I thought I had some terrible disease or something.

I remember the only time I ever saw my mother cry. I was eating apricot pie.

I remember how much I cried seeing South Pacific (the movie) three times.

I remember how good a glass of water can taste after a dish of ice cream. (8)

The consecutive entries, as can be seen above, do not engage with one another in any discernible way and do not constitute a chronological or cause-and-effect sequence. The only common denominator, besides the remembering " $I$," is the focus on childhood, although even that is not certain since the second and fourth entries could also refer to later periods in the author's life.

The random arrangement of recollections could be interpreted as mirroring the often incomprehensible mechanisms of memory. Such a reading would situate I Remember alongside B. S. Johnson's autobiographical novel-in-a-box The Unfortunates (1969), whose 27 unbound sections present the author's recollections of his dead friend Tony Tillinghast. Johnson's experiment, as his biographer Jonathan Coe argues, was the wish to "record with absolute fidelity" the "randomness" and "lack of structure" of memory (ix). Although both the title and the opening words of the book's formula emphasize the process of remembrance, no critic to date has pursued that interpretive avenue.

As for the arrangement of entries in I Remember, many of them take the form of a paratactic list - a grouping of remembered objects arbitrarily juxtaposed, reminiscent of the "I like, I don't like" section in Barthes by Barthes:

I remember canasta.

I remember "How Much Is That Doggie in the Window?"

I remember butter and sugar sandwiches.

I remember Pat Boone and "Love Letters in the Sand." (13) 
This manner of incorporating intertexts such as songs, films and celebrities, grants the text a collage-like quality. ${ }^{7}$ Works of pop culture and iconic personages (such as Marilyn Monroe, who features in seven entries) from the 1950s and 60s function in I Remember as readymadessimilar to the appropriated newspaper cuttings in the backdrop of Pablo Picasso's and Georges Braque's first collages. They also provide a cultural and historical anchoring of Brainard's more personal memories. ${ }^{8}$

Besides collage, critics have likened Brainard's arrangement of his recollections to an assemblage (Laing), a mosaic (Fitch 78) and a litany (Epstein). While most of those propositions seek parallels in various genres of visual arts, Paul Auster, in his introduction to The Collected Writings of Joe Brainard, suggests the musical analogues of "counterpoint, fugue, and repetition, the interweaving of several different voices." Auster argues that I Remember is "a concerto for multiple instruments," in which "a theme is picked up for a while, then dropped, then picked up again." Among the dominant themes which recur throughout the entire work he numbers family, food, clothes, popular culture, school and church, the body, sex and "dreams, daydreams and fantasies." Rather than see I Remember as a random mixture of all kinds of memories, Auster traces a subtle polyphonic pattern. His argument can be substantiated by the fact that Brainard does occasionally group several memories focusing on a specific topic. At one point, across five consecutive passages three concern Frank O'Hara. The first gives an account of Brainard's first encounter with the poet (and his later artistic collaborator), the second-coming after two irrelevant snippets-is a memory of learning bridge in order to play with O'Hara, and the third is a recollection of actually playing bridge with him (15). The infrequent occurrence of such blocks does not seem to justify the parallel with the form of the fugue, which is one of the most regular and meticulously structured musical forms.

In his discussion of the recurrent themes in I Remember, Auster mentions "autobiographical fragments" as a strand amounting to merely twenty entries but "fundamental to our understanding of his project, his life." Out of those scattered passages, the reader can construct a biographical overview of Brainard's life-the uneventful childhood in

7 Collage was also Brainard's adopted strategy in most of his best known visual works such as I'm Not Really Flying I'm Thinking (1964, co-authored with Frank O'Hara), Collage with Pressed Poppy (1976), Untitled (Heinz) (1977) and his series of works featuring Nancy - a character from Ernie Bushmiller's comic strip.

8 In "Blowing up Paper Bags to Pop: Joe Brainard's Almost-Autobiographical Assemblage," Andrew Fitch considers I Remember as an example of what he calls "popography" - a life writing genre stressing the dependence of individual experience on the mass media and popular culture. 
Tulsa, the arrival in the dazzling New York City, the discovery of its gay scene, the brief stints at the Dayton Art Institute and in Boston, and the choice of artistic vocation. However, I would argue that the number of autobiographical fragments is much greater than twenty; in fact, it could be said to equal the total number of entries in I Remember, however trivial (e.g., "I remember playing 'doctor' in the closet" [12]) or impersonal ("I remember the day John Kennedy was shot" [9]) they might seem. Brainard's "cute childhood memories”-to use Fitch's phrasing (80)—also contribute to the reader's understanding of the autobiographical subject, as they offer an intimate insight into his formative years. The evocations of external events, celebrities and popular products-despite their apparent outward rather than inward focus - are all preceded by the "I remember" formula and thus filtered through Brainard's perspective. As mentioned before, they provide the social and cultural backdrop against which the more overtly personal memories emerge.

A substantial part of I Remember is constituted by what Auster calls "dreams, daydreams, and fantasies," "insights" and "musings ... which track the various stray thoughts that come flying in and out of consciousness." Those categories are exemplified by the following passages:

I remember daydreams of being a singer all alone on a big stage with no scenery, just one spotlight on me, singing my heart out, and moving my audience to total tears of love and affection. (29)

I remember not understanding why people on the other side of the world didn't fall off. (46)

I remember being disappointed in Europe that I didn't feel any different. (51) I remember, at parties, after you've said all you can think of to say to a person-but there you both stand. (149)

If such meditations do not belong in a traditional autobiography, they are a staple ingredient of experimental life writing such as Barthes by Barthes. In both books, as has already been suggested, it is the mind of its subject, rather than their achievements and exploits, that becomes the focal point.

Perhaps the most important parallels with Barthes, especially in the context of this article, are the resistance to the temptation to turn one's life into a story and the related wariness of "fixing" or "constituting" oneself by embracing a specific identity. Although many of Brainard's individual memories could be subsumed under particular conventional autobiographical narratives-such as coming-of-age, the gradual acceptance of one's homosexuality, moving from the provinces to a metropolis and becoming an artist - he is careful not to allow any of them to consolidate and reduce his experience to a formula or a cliché. 
Brainard resists the wiles of narrative and identity in three ways. First of all, by fragmenting the record of his experience into individual glimpses and shuffling their order, he invites the reader to perceive his past as an amalgam of moments and events rather than as a sequence leading up to the emergence of Joe Brainard - the artist, the New Yorker, the homosexual. ${ }^{9}$ Secondly, he incorporates entries which subtly undermine the coherence or consistency of the above-mentioned autobiographical narratives. The scattered fragments of a potential Künstlerroman story-line, for instance, contain descriptions of failures rather than successes ("I remember the day Frank O'Hara died. I tried to do a painting somehow especially for him.... And it turned out awful” [13]) and refer to art with playfulness rather than reverence (". . .I tried to do an oil painting using my dick as a brush" [10]). Most importantly, they do not culminate in the author's realization of his artistic talent, which would single him out from the rest of society. On the contrary, Brainard notes, "I remember when I thought that I was a great artist" (21). The refusal to deliver the expected narrative resolution is also frequently evident on the level of the individual passage, such as this micro story of adolescent love: "I remember getting up at a certain hour every morning to walk down the street to pass a certain boy on his way to work. One morning I finally said hello to him and from then on we said hello to each other. But that was as far as it went" (165). The final, anticlimactic sentence disappoints the expectation of a development of the relationship and denies closure.

The third strategy through which Brainard opposes "fixing" himself and his life-story is presenting much of his experience as universal rather than unique and self-defining. I Remember abounds in accounts of memories which are highly relatable to Brainard's contemporaries, as well as to readers born decades later and in countries very different from America. ${ }^{10}$ Here is a small selection of such entries:

I remember daydreams of dying and how unhappy everybody would be. (29) I remember staying in the bathtub too long and having wrinkled toes and fingers. (54)

I remember being embarrassed to buy toilet paper at the corner store unless there were several other things to buy too. (61)

9 Brainard's lack of self-importance and his capacity for satirizing himself can be gleaned from the following passage: "I remember changing my name to Bo Jainard for about one week" (166).

10 My experience of teaching I Remember over four consecutive years to undergraduate and postgraduate students at the University of Wrocław in Poland allows me to conclude that such transgenerational and transnational relatability does indeed apply in the case of Brainard's memories. 
I remember walking home from school through the leaves alongside the curb. (88)

I remember the fear of not getting a present for someone who might give me one. (90)

In those entries, Brainard articulates a number of minor anxieties, realizations and passing thoughts that would have been experienced by most of his readers. For that reason, Gary Weissman sees I Remember as a work that "questions just how unique and idiosyncratic are one's most private and personal experiences and sentiments" and evokes a "sense of how much one is like others" (78).

Brainard's letter to a fellow writer from 1969 bears witness to the fact that the author was aware of creating more than a mere record of one's own past and that his ambitions were very high, if not grandiose:

I feel very much like God writing the Bible. I mean, I feel like I am not really writing it but that it is because of me that it is being written. I also feel that it is about everybody else as much as it is about me. And that pleases me. I mean, I feel like I am everybody. And it's a nice feeling. It won't last. But I am enjoying it while I can. (qtd. in Padgett 171)

Brainard admits to entertaining a utopian wish to render his life in such a way as to embrace everyone and assume a collective subjectivity, thus renouncing, or at least suspending, his individual self. The realization that this sense of communing with humanity cannot be made to last does not, for Brainard, render his project futile.

It is curious that this Whitmanesque ambition to "contain multitudes" and be the spokesman for the entire humanity is harboured by a writer whose formative years must have been markedly different from most people on account of his homosexuality, which, in Oklahoma in the 1950s, was far from accepted. Brainard does not downplay his queer experience; on the contrary, he is very forthcoming and explicit about his failed heterosexual attempts, his homoerotic infatuations, homosexual exploits and fantasies, and his struggle with shame- the foundation of queer experience according to Eve Kosofsky Sedgwick. Despite the occurrence of these motifs, I Remember should not be classified as a gay autobiography, which would be too narrow a label for what Brainard aims to achieve, as Krzysztof Zabłocki argues in his afterword to the first Polish edition of the book (232). ${ }^{11}$ According to

11 It is interesting to note the surprising lack of a sociopolitical dimension in I Remember. After all, the Stonewall riots, regarded as the beginning of the gay rights movement, took part in New York City in 1969, which is where and when Brainard was living and working on the book. 
Auster, regardless of the unavoidable disparities between Brainard's and his readers' experience, the "self-effacing" author's portrayal of his life is "so precise and uninhibited in its telling" that readers "inevitably begin to see [their] own lives portrayed in his."

To conclude, I Remember, Brainard's life-in-fragments, employs several strategies regarding the formal arrangement of its components, as well as their content, which are meant to resist the conventional reliance of autobiography on a coherent life-narrative and its product-a single and stable identity. In line with the politics of fragmentary life writing, it does not aim to make sense of the existence it represents or suggest any interpretive patterns. The definition of life offered in the final sentence of Barthes by Barthes- "encounters, friendships, loves, travels, readings, pleasures, fears, beliefs, satisfactions, indignations, distresses"-could serve as an apt summary of I Remember and other examples of the genre, such as Gregory Burnham's "Subtotals" (1989). In this humorous 321word register of autobiographical facts, significant and trivial, Burnham evokes the sense of life experience as an accumulation of random incidents:

Number of refrigerators I've lived with: 18. Number of rotten eggs I've thrown: 1. Number of finger rings I've owned: 3 . Number of broken bones: 0 . Number of Purple Hearts: 0 . Number of holes in one, big golf: 0; miniature golf: 3 . Number of consecutive push-ups, maximum: 25. Number of times I've kicked the dog: 6. Number of times caught in the act, any act: 64 . Number of postcards sent: 831 ; received: 416. . . (Burnham 207)

In both "Subtotals" and I Remember, an intimate insight into a life is afforded by means of a part-for-the-whole synecdoche-an autobiographical detail, or fragment. A similar artistic strategy was adopted by Brainard in his drawing entitled Self-Portrait (My Underwear) (1966), where the artist's crumpled pants have been arbitrarily, and playfully, chosen to stand for the artist himself.

As attested by the popularity and critical recognition of Maggie Nelson's Bluets (2009) - a memoir composed of 240 numbered meditations on loss, heartbreak, depression and the colour blue-and The Argonauts (2015) - the award-winning and genre-bending exploration of gender prompted by Nelson's relationship with her partner Harry Dodge, the development of fragmentary life writing is gaining momentum. And so is the recognition earned by I Remember, which is used these days as a creative exercise "wherever writing courses are taught, whether for children, college students, or the very old" (Auster). According to Weissman, it is because 
Brainard has tapped into the current Zeitgeist. His entries— "in their brevity and co-mingling of the candid, the idiosyncratic and the banal"-may be viewed as anticipating the sort of autobiographical writing practised today through social media such as Facebook and Twitter (98). The more recent and future examples of fragmentary life writing may also take advantage of the twenty-first-century reader's increasing preference for texts broken down into bite-size portions and help this niche, experimental genre enter the literary mainstream.

\section{WORKS CiTED}

Ashbery, John. "Joe Brainard.” Joe Brainard: A Retrospective. Ed. Constance M. Lewallen. Berkeley: Berkeley Art Museum, 2001. 1-2. Print.

Auster, Paul. Introduction. The Collected Writings of Joe Brainard. Library of America, 2012. E-Book.

Barthes, Roland. Roland Barthes by Roland Barthes. Trans. Richard Howard. New York: Hill and Wang, 2010. Print.

Brainard, Joe. I Remember. New York: Granary, 2001. Print.

Burnham, Gregory. "Subtotals." Life Is Short-Art Is Shorter: In Praise of Brevity. Ed. David Shields and Elizabeth Cooperman. Portland: Hawthorne, 2014. 207-08. Print.

Coe, Jonathan. Like a Fiery Elephant: The Story of B. S. Johnson. London: Picador, 2004. Print.

Eakin, Paul John. How Our Lives Become Stories: Making Selves. Ithaca: Cornell UP, 1999. Print.

Epstein, Andrew. “'To the Memory of Joe Brainard': Kent Johnson’s I Once Met.” Newyorkschoolpoets.wordpress.com. New York School Poets 20 Aug. 2015. Web. 29 Jun. 2018.

Fitch, Andrew. "Blowing up Paper Bags to Pop: Joe Brainard's AlmostAutobiographical Assemblage.” Life Writing 6.1 (2009): 77-95. Print.

Kacandes, Irene. "Experimental Life Writing." The Routledge Companion to Experimental Literature. Ed. Joe Bray, Alison Gibbons and Brian McHale. London: Routledge, 2012. 380-92. Print.

Kennedy, J. Gerald. "Roland Barthes, Autobiography, and the End of Writing." The Georgia Review 35.2 (1981): 381-98. Print.

Laing, Olivia. Rev. of I Remember, by Joe Brainard. Guardian.co.nk. Guardian 7 Apr. 2013. Web. 30 Jun. 2018.

Lejeune, Philippe. On Autobiography. Trans. Katherine Leary. Minneapolis: U of Minnesota P, 1989. Print.

Padgett, Ron. Afterword. I Remember. By Joe Brainard. New York: Granary, 2001. 169-76. Print. 
Phillips, Adam. Foreword. Roland Barthes by Roland Barthes. By Roland Barthes. New York: Hill and Wang, 2010. v-xv. Print.

Ricoeur, Paul. "Narrative Identity.” Philosophy Today 35.1 (1991): 73-81. Print.

Simms, Karl. Paul Ricoeur. London: Routledge, 2003. Print.

Smith, Sidonie, and Julia Watson. Reading Autobiography: A Guide for Interpreting Life Narratives. Minneapolis: U of Minnesota P, 2001. Print.

Weissman, Gary. “II Feel Like I Am Everybody’: Teaching Strategies for Reading Self and Other in Joe Brainard's I Remember." Reader 60 (2010): 71-102. Print.

Zabłocki, Krzysztof. "Od tłumacza." I Remember. By Joe Brainard. Kraków: Lokator, 2014. 221-33. Print.

Wojciech Drąg is Assistant Professor at the Institute of English Studies, University of Wrocław. He is the author of Revisiting Loss: Memory, Trauma and Nostalgia in the Novels of Kazuo Ishiguro (2014) and co-editor of War and Words: Representations of Military Conflict in Literature and the Media (2015), Spectrum of Emotions: From Love to Grief (2016) and The Poetics of Fragmentation in Contemporary British and American Fiction (2019). In 2018, he received The Kosciuszko Foundation fellowship at the University of Utah.

wojciech.drag@uwr.edu.pl 